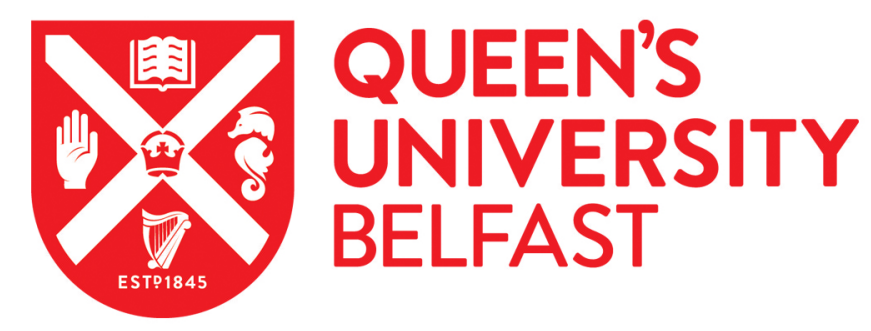

\title{
Navigating consociationalism's afterlives: Women, peace and security in post-dayton Bosnia-Herzegovina
}

Deiana, M-A. (2018). Navigating consociationalism's afterlives: Women, peace and security in post-dayton Bosnia-Herzegovina. Nationalism and Ethnic Politics, 24(1), 33-49.

https://doi.org/10.1080/13537113.2017.1422638

Published in:

Nationalism and Ethnic Politics

Document Version:

Peer reviewed version

Queen's University Belfast - Research Portal:

Link to publication record in Queen's University Belfast Research Portal

Publisher rights

Copyright @ 2018 Informa UK Limited trading as Taylor \& Francis.

This work is made available online in accordance with the publisher's policies. Please refer to any applicable terms of use of the publisher.

\section{General rights}

Copyright for the publications made accessible via the Queen's University Belfast Research Portal is retained by the author(s) and / or other copyright owners and it is a condition of accessing these publications that users recognise and abide by the legal requirements associated with these rights.

Take down policy

The Research Portal is Queen's institutional repository that provides access to Queen's research output. Every effort has been made to ensure that content in the Research Portal does not infringe any person's rights, or applicable UK laws. If you discover content in the Research Portal that you believe breaches copyright or violates any law, please contact openaccess@qub.ac.uk. 


\title{
Navigating Dayton's Afterlives: \\ Women, Peace \& Security in Bosnia-Herzegovina \\ Maria-Adriana Deiana, m.deiana@qub.ac.uk
}

School of History, Anthropology, Politics and Philosophy, Queen's University Belfast.

Accepted manuscript, Nationalism and Ethnic Politics,

24:1, 33-49, DOI: 10.1080/13537113.2017.1422638

\begin{abstract}
This paper revisits the gendered implications of the Dayton peace settlement and assesses possibilities for the meaningful integration of the Women, Peace and Security agenda into the consociational structures and post-conflict political agenda. The context of Bosnia-Herzegovina illustrates longstanding gendered ramifications as a by-product of consociationalism, reaching beyond the rhetorical commitment to women's political representation and gender equality. The paper outlines how the reification and legitimisation of ethnonationalist power over two decades of Dayton has increasingly restricted the terrain for gender activism. A critical assessment of the post-Dayton governance reveals an unanticipated stratification of the agreement. Coupled with international pressure for the stability of the peace settlement, this outcome adds further constraints to the complex task of addressing the gendered legacy of conflict and conflict transformation. In this context, various local/international efforts to navigate Dayton's afterlives through gender activism act as a powerful reminder that the Bosnia-Herzegovina's unfulfilled peace must remain a priority in research, activist and policymaking agendas.
\end{abstract}

Keywords: Bosnia-Herzegovina, gender activism, ethnography, Dayton Peace Agreement, consociationalism

\section{Introduction: Competing Paradigms for Peace and Security?}

This paper examines a specific tension emerged between the aspiration for transformation and inclusion set out in the Women, Peace and Security Agenda (WPS) and one of the most popular conflict resolution theory and practice: consociational peace settlements. Despite the diffusion of power-sharing solutions, the gendered implications of consociationalism remain a relatively unexplored area of inquiry within the extensive body of literature on Women, Peace and Security. ${ }^{1}$ Important feminist analyses, however, 
have begun to delve into consociationalism's 'darker' outcomes for women. ${ }^{2}$ This literature points out that by entrenching conservative ethnonationalist discourses, power-sharing peace settlements often also implicitly cement patriarchal values. By reifying the divisions they seek to overcome, consociational settlements essentially work to restrict the political space for introducing other interests and agendas, such as WPS. Given the extensive deployment and persistence of these institutional arrangements in many post-conflict contexts, Christine Bell argues for a more systematic analysis that foregrounds women's experiences of/in power-sharing settlements. ${ }^{3}$ As Siobhan Byrne and Allison McCulloch illustrate, while the tension between women's political participation and consociational power-sharing might be resolved in theory, in practice the gendered implications of power-sharing pacts are much more resilient. ${ }^{4}$ Gathering empirical evidence into the specifics of consociational settings, thus, spotlights ways in which women and gender activists navigate these structures. ${ }^{5}$

In this paper, I build on and develop these insights by bringing to the fore the post-conflict/postsettlement scenario of Bosnia-Herzegovina $(\mathrm{BiH})$. While existing feminist analyses focus predominantly on women's political representation, here I suggest that the gendered ramifications are further reaching. Drawing on multiple sets of interview and ethnographic data collected in BosniaHerzegovina, I illustrate how Dayton's gender implications reach beyond the political structures and infiltrate the social and discursive fabric of the post-war/post-agreement order in ways that further complicate attempts at fully implementing WPS. The paper reflects a long-standing interest of mine in researching alternative spaces for feminist activism vis a vis the institutionalisation of ethnic citizenship as a by-product of the agreement. Between 2010-2015 I have conducted 30 in-depth interviews with feminists, civil society activists, academics, individuals working in cultural production and the media, as well some members of political parties and officials in (local and international) gender machinery institutions, based in Sarajevo, Mostar and Banja Luka. ${ }^{6}$ Given my interest in gauging broader dynamics beyond the strictly institutional domain, other methods included observation and participation at cultural events, meetings and conferences organised by activists. ${ }^{7}$ With a few notable exceptions, most interviews reflect experiences at the grassroots level or in the more formalised NGO sector. In 2016, I conducted further research and interviews with a view of assessing developments and challenges for the implementation of the Women, Peace and Security agenda ${ }^{8}$. This offered additional insights into various local/international efforts to navigate Dayton's counter-effects.

The post-Dayton scenario raises critical questions about the possibilities of meaningfully integrating the WPS agenda into its consociational architecture, political culture and the divisions it has sustained over the decades. More specifically I argue that undercutting WPS transformative prospects is the intersection between dysfunctions associated with corporate consociationalism, the resulting entrenchment of ethno-nationalism in political life, and the implicit proliferation of its attendant gender rhetoric. In this context, the divisive nature of ethno-national politics inevitably takes centre stage. Gender concerns are often relegated to the margins of dominant political agenda and held hostage of 
what I define an 'ethno-national straightjacket". Alternatively, they get caught up in slow-decision making, political deadlock and unaccountability which, perversely, the consociational provisions have enabled. While it is possible to identify a range of actors who attempt to circumnavigate these constraints, the ability of WPS to advance the status of women and reshape the meaning of Dayton's peace and security has been inevitably limited. New strategic partnerships within and beyond the local political context might offer opportunities for transformation. I suggest that this potential also depends on a collective effort to ensure that Bosnia-Herzegovina's incomplete peace remains a priority in research, activist and policymaking agendas.

The next section outlines key gendered features of the Dayton Peace Agreement (DPA) and the efforts to address these tensions in its implementation. Then, drawing on interview data and observations, I discuss long-standing gendered ramifications and the implications these hold for women's status and agency in the post-Dayton order. Finally, I examine the critical and generative potential of sustained activism in challenging "post-conflict/post-Dayton" gendered exclusions.

\section{The Dayton Peace Settlement: from Gender Blindness to Rhetorical Commitment.}

Despite the complex gender dynamics highlighted in the emergence of nationalism and the successive years of conflict, the peace negotiations failed to include gender as a key dimension for addressing the legacy of the Bosnian war and building sustainable peace. ${ }^{9}$ This is unsurprising given that, from the onset of negotiations, the Dayton peace process was a politico-military process with a key aim of putting an end to the war. Indisputably the agreement was successful insofar as it stopped the atrocities and offered a settlement for the warring parties. However, despite an impressive annex of human rights mechanisms, the final document of the DPA failed to specifically address the varied impact of conflict on men and women, to include specific measures to tackle the gender dynamics underpinning war and peace and ensure women's participation as co-architects of the peace process. ${ }^{10}$

Since the signing of the Agreement, lobbying from local and international women's groups led to the creation of a multi-level institutional gender mechanism, the adoption of the Law on Gender Equality by the $\mathrm{BiH}$ parliament (2003) and the development of a national Gender Action Plan (2006), informed by CEDAW, The Beijing Platform for Action and to an extent by UN Security Council Resolution 1325- Women, Peace and Security. ${ }^{11}$ In 2010, the government of BiH, through its Gender Agency and the Ministry of Human Rights and Refugees, adopted the first National Action Plan (NAP) for the implementation of UNCSR1325 and its sister resolutions. Bosnia-Herzegovina was one of the first postconflict countries to develop a NAP and include a monitoring system of indicators. ${ }^{12}$ Regarded as an example of best practice, the plan comprised of an ambitious set of key objectives: increasing women's participation in decision-making, reforming the security sector and peacekeeping operations through gender sensitive measures, protecting the human rights of women and girls which interestingly groups 
together demining, human trafficking and addressing the needs of women and girls civilian victims of war, and training of civil servants for the full implementation of UNSCR1325. ${ }^{13}$

Policy developments have contributed to enhancing women's human rights legislation, making women and gender concerns visible in the public and institutional sphere. The adoption of the NAP for UNSCR1325 and the initial phase of implementation focused mainly on the reform of the security sector and training of civil servants and civil society groups. This phase was effective insofar as it has provided an opportunity for cooperation among state officials and civil society groups, as well as raising awareness around UNSCR1325 as a strategic tool. The second NAP for UNCSR1325 (2014-2017) has seen an improved implementation and monitoring mechanisms that revolves around a re-orientation of the agenda following the pillars of Equal Participation, Prevention and Protection. ${ }^{14}$. As Ankica Tomić notes, this led to the inclusion of clearer objectives and expected results, and a more focused and efficient monitoring system. ${ }^{15}$ Reflecting international developments and trends in the local diffusion and translation of the agenda, the formulation of the second NAP raises ambivalent expectations about its impact. ${ }^{16}$ On the one hand, the NAP relies on a compromised programme of reform that focuses predominantly on women's inclusion in institutions and the security sector. One the other, it includes provisions that might positively draw in local authorities to carry out WPS project at the micro-political level. However, whether there is political will to take the transformative ethos of WPS seriously remains an issue. The consociational formula has laid the foundations for long-term political paralysis and enabled the local elites to mobilise ethnonationalist rhetoric to stay in power with significant gendered effects.

\section{Dayton at 20+: Gendered Reverberations within and beyond the political structures.}

Obstacles to the full implementation of WPS commitments have been experienced globally to a greater or lesser extent. ${ }^{17}$ In the context of BIH, I suggest that these challenges are intensified by the dysfunctional "afterlives" of corporate consociationalism and the resulting entrenchment in political life of ethno-nationalism and its attendant gender rhetoric. The Agreement produced a complex multitiered system made of state level institutions, two separate entities, the Republika Srpska (RS) and the Croat-Bosniak Federation, made up of ten cantons, and the internationally supervised Brčko district. Following the corporate formula, group representation has been ascribed a priori on the grounds of ethnic affiliation. This principle is enshrined in the Constitution where Bosniaks, Croats and Serbs figure as The Three Constituent People, and the category of "the Others" is essentially disenfranchised from political representation. ${ }^{18}$ The agreement's corporate nature has worked to entrench ethnic divisions in the post-conflict structures, as well as in political, social and cultural life. While the peace settlement might have been successful in creating shared institutions and mitigating violence, it has also laid the foundation for political paralysis and restricted the political space to ethnonational disputes. 
This has come at the price of marginalising gender concerns in favour of dominant ethnic affiliation and nationalist politics as all-encompassing dimension of citizenship, peace and security.

All rhetoric to the contrary, international actors have also contributed to the dysfunctional afterlives of the agreement. ${ }^{19} \mathrm{EU}$ emphasis on stability, for example, has worked to further legitimise the modus operandi of ethnonationalist elites. The accession process set in motion a protracted kafkaesque scenario, wherein many of the parties tasked with implementing reforms to successfully join the EU are indeed the very political elites benefiting from Dayton's regime of permanent crisis. ${ }^{20}$ In 2013 this approach had important gendered implications. During EU-led talks on constitutional reform and accountability, local women's NGOs and individual activists lobbied for the inclusion of gender discrimination among the issues to be renegotiated. They also issued demands for a more transparent and participatory process as 'the basis for establishing a truly functional and democratic society'. ${ }^{21}$ Not only were demands largely neglected with negotiations continuing behind closed doors, but in the name of stability the EU also implicitly re-confirmed the legitimacy of ethnonational elites as the key political interlocutors for deciding the course of peace.

Dayton's afterlives might explain why, despite an impressive mechanism for gender equality and two consecutive WPS Action Plans, commitment has been rhetorical at best and success in implementation minimal. Two decades after the ratification of the peace agreement, the corporate consociational settlement has mutated into an apparatus that is dysfunctional, unresponsive and removed from everyday politics. ${ }^{22}$ The group right provisions established through the agreement have been conducive to prolonged political deadlock and slow decision-making. Furthermore, through predetermined group representation and protection mechanism, the DPA's corporate system has offered lucrative opportunities for ethnonationalist elites to remain in power without incentives to alter their rhetoric. ${ }^{23}$ Not only has this allowed elites to dominate the political process for their own gains, but policy and decision-making have neglected basic issues and citizens' rights, such as education, health and employment.

Such dysfunctions are visible in the context of gender policies. For instance, despite the system of gender quotas, the percentage of women in legislative and executive authorities at all levels remains low. The situation has improved since 1996 when the percentage of women in the Parliamentary Assembly of Bosnia and Herzegovina was only 2\%. However, in 2014, only $19 \%$ of women were represented in the Parliament of $\mathrm{BiH}, 21.4 \%$ in the House of Representatives of $\mathrm{BiH}$ and $13.3 \%$ in the House of the Peoples of BiH. The 2014 election results confirm this trend with $21.4 \%$ women in the House of Representatives and 13.3\% in the House of the Peoples of $\mathrm{BiH}^{24}$ In the 2016 local election out of 417 mayoral candidates only 26 were women. ${ }^{25}$ Interviews suggest that low levels of women's political representation cannot be understood as a matter of imperfect or unsuccessful quota implementation. Rather, research participants point to the broader culture underpinning dominant 
parties and socio-political life which, in their view, creates a hostile environment to women's political engagement.

\section{Dayton and the Nationalist Politics of Gender}

Notwithstanding that the Law on Gender Equality has provided strong legal foundations for women's political participation and that women's presence in elected office has improved from the early 1990s, intersecting forces undermine women's political participation and citizenship. These include a rhetorical commitment to gender equality, the entrenchment of a traditional gender order supported by national political parties, as well as Dayton's restrictive terrain of politics. In a forerunning analysis of $\mathrm{BiH}$ gender politics and activism, Elissa Helms illustrates how since the aftermath of the war, many women activists saw politics as an activity associated with male power, lack of transparency and corruption. ${ }^{26}$ While $\mathrm{BiH}$ citizens have increasingly expressed disillusionment with politics and the nationalist elites, the subtext often implied is that politics is an unsuitable space/activity for women. Helms points out how this connotation reproduces problematic gender tropes of women's purity/innocence vs. the male domain of corrupted politics. ${ }^{27}$ In turn, this logic reinforces gendered exclusions in political participation, as well as pressures for the (few) women who enter politics to reassert their traditional roles. ${ }^{28}$

Echoing this argument, a recent study undertaken by the feminist organisation Sarajevo Open Center indicates that obstacles to women's political participation continue to stem from "the traditional perceptions of women within society; women are perceived as mothers, wives and homemakers, while their ambitions, wants, and needs to be politically active are ignored." ${ }^{29}$ Feminist activists I interviewed expressed similar critical views on political life in Post-Dayton $\mathrm{BiH}$ as intrinsically linked to male networks of (predominantly nationalist) elites. Their dissatisfaction with corrupted formal politics, however, revolved predominantly on its configuration as a domain often inaccessible and hostile to women's participation, and more so to feminist concerns. ${ }^{30}$ Interviewees viewed Post-Dayton formal politics as a domain where questions of gender, civic activism and everyday political issues, such as healthcare, unemployment and issuing of documents, are routinely marginalised in favour ethnonationalist interests and disputes. ${ }^{31}$ In other words, their wariness of formal politics points to the interaction between nationalism and consociationalism, as practiced in Post-Dayton BiH.

Conservative gender tropes are part and parcel of the nationalist rhetoric deployed by local elites wherein gender issues are strategically mobilised or silenced with the purpose of holding the grip on power. I argue that by creating the conditions of possibility for the entrenchment of nationalist politics, Dayton's consociational formula has also implicitly contributed to legitimise its ambivalent gender politics. In 2010, an interview with one of the few women elected representatives, House of the People deputy speaker and member of nationalist party Alliance of Independent Social Democrats (SNSD) ${ }^{32}$, provided a stark illustration of these tensions. On the one hand, my interlocutor detailed her personal 
and institutional support for gender equality and women's equal representation within politics. Yet, when I asked for her views on the gendered nature of ethno-nationalist politics and the primacy of ethnonationalist interests, she had no hesitation in stating:

"We had a bloody war here in $\mathrm{BiH}$ and this is something which defines all our activities. You know that we, the nations and the people do not have trust in each other. People are frightened that somebody else could take their rights, including the rights to make decisions. The main issue is what the three main Nations that live here will do to make the country in which they live, how the country will look like and how will they create the country. [...]Bosniak people, because they are majority, believe that they have the possibility to overcome the other two nations. According to the Serbs, $\mathrm{BiH}$ in the way which was created by Dayton peace agreement should be unquestionable and so Republika Srpska is unquestionable because it was created according to Dayton. The Croats which live in the federation together with Bosniak people are not happy and also ask for their issue to be solved. So, once you know all these facts you can see that the issue of women is not the most important one. The most important issue is can we live together? ${ }^{33}$

This tension still rings true today and suggests that broader changes outside the strictly legal and institutional domain are difficult to achieve, particularly when these would undermine the primacy of ethnonational interests that consociationalism has implicitly enshrined in political life. For instance, a local gender expert whom I interviewed reported that nationalist elites continue to rely on a rhetoric that reduces women's role to motherhood and narrowly defines the acceptable parameters of women's behaviour.

"I think that the whole concept of feminism within the political nationalist ideological project is even more difficult because even social-democrats think that feminists are witches. It is a general popular belief that feminist is really not something that you want to be, apart from among the feminists. The nationalist parties are trying to do their best to mask their misogyny and male chauvinism by supporting $\{.$.$\} social welfare$ programmes, you know, and constantly around the role of women as a mother.

These ideological projects are also making a huge pressure on women on how they should behave in order to respond to the role of a good Bosnian woman, good Croatian woman or good Serbian woman. There are a list of things that you have to do to be a good Serbian, etc. woman and I think that this is making a huge pressure on women, and huge expectations on how they should behave" 34

Echoing these findings, researchers point to the re-patriarchalization of social values and gender roles, initiated with the emergence of nationalist politics and sustained by the consociational settlement. ${ }^{35}$ This process is crucial to understand post-war/post-Dayton failure to tackle gender inequalities. After two decades of post-conflict transformation the implications of this regression reverberate in socio-political life. Interviews and my observations suggest that strong social pressure is in place to silence, discredit and often intimidate women and feminists who dare to openly critique the correlations between the current status-quo, the nationalist grip on power and the gender inequalities underlying nationalist politics. For instance, an interviewee working in the Federation broadcasting service, described how in 2010 she became the target of a media campaign that, she argued, was connected to her dismissal from her position in the Federation $\mathrm{TV}^{36}$. There are reasons to believe that the journalist, who is renowned 
for her media inquests into episodes of corruption involving nationalist elites, became a target of harassment for her outspoken anti-nationalist stance. In a more recent controversy, president of Republika Srpska, Mirolad Dodik, publicly attacked Oslobodienje journalist Gordana Katana on the grounds of her gender and ethnicity. She dared to ask Dodik to comment on a series of accusations for illicit activities against a relative. ${ }^{37}$

Similarly, a local activist within a LGBTQ organisation recounted having experienced various forms of harassment and threats from sympathisers of nationalist parties because of their identity and politics as LGBTQ collective and their work against enforced ethnonationalist rhetoric. ${ }^{38}$ These episodes spotlight tensions between institutional support for gender equality politicies and the dominance of nationalist elites. On the one hand, institutional instruments such the WPS National Action Plan and the Gender Action Plan express the BiH government's commitment to increase women's participation in all levels of decision-making. Yet dominant political elites continue to prioritise nationalist interests and rely on the manipulation of the gendered legacy of war to ensure support for their agenda. As a result, gender dimensions of post-conflict transformation are often side-lined or held hostage of larger power dispute.

These dynamics are salient to understand the ongoing resistance to fully acknowledge the status and rights of civilian victims of war to survivors of war-time rape, despite institutional commitment to implement UNSCR1325. Discrepancies in the law regulating access to social rights and pensions are still in place. Reparations so far have focused mainly on male veterans and the fighting against impunity of perpetrators is still ongoing. ${ }^{39}$ The failure to adequately address the legacy of wartime rape lies in its deep entanglement with ethnonational interests and attendant gender narratives. ${ }^{40}$ It is intertwined with larger disputes over responsibility of war crimes and tropes about innocence and victimhood that are often mobilised to ensure support for nationalist agendas, a strategy that becomes particularly visible during election times. As Maria O'Reilly's extensive research on gender and transitional justice illustrates: "these gaps and deficiencies have precluded just recognition, redistribution and representation for many survivors by failing to acknowledge harms incurred by many victims, satisfy demands for material and symbolic reparations and provide a public platform to voice experiences." ${ }^{\prime 1}$ After two decades of peace process, addressing the status and rights of survivors of war-time sexual violence remains an outstanding legacy that undercuts the institutional commitment to the Women, Peace and Security Agenda. Crucially, Dayton's consociation has provided the institutional environment where nationalist elites could pursue this gender politics relatively unchallenged.

\section{Navigating Dayton's Afterlives through Gender Activism}

The dynamics discussed so far indicate that the DPA's dysfunctional afterlives inevitably limit the political terrain in which gender activism and advocacy operate. Despite these constraints women and feminist activists continue to mobilise for change. Interviews reveal two broad set of mobilisation strategies: some feminist activists and groups choose to focus their efforts at the grassroots level and 
inscribe activism within broader instances of civic mobilisation, while others work strategically to infiltrate and reform the existing consociational structures.

Since the end of the war, the informal space of grassroots activism has been crucial in providing an alternative bottom-up approach to addressing women's concerns and citizenship claims. ${ }^{42}$ While the grassroots provide an important space for feminist politics, subverting and challenging the multi-layered structural constraints of institutional politics remains a huge challenge despite activists' efforts. A poignant example is the new course taken by the feminist organisation Crvena. From an initial focus on feminist art, culture and regional cooperation, in 2014 Crvena's interventions grew to encompass broader political demands enacted by the recent movements of popular protest, emerged in $2014 .{ }^{43}$ During our conversation in 2015, Crvena activists explained that the waves of popular mobilisation held in 2014 ushered in a new political language and opportunities for radical action beyond the usual ethnonationalist narratives and disputes. ${ }^{44}$ They viewed the protest movement as an unprecedented opening to inscribe feminist activism within larger concerns over the structural inequality and multilayered violence epitomised in the Dayton's mode of governance, as well as the commodification of feminism supported by international donors. Even though its more ambitious objectives were curtailed by the end of the plenums movement, the citizen-led experiment in radical politics provided an important, albeit, momentarily, opening to challenge the Dayton's status quo. ${ }^{45}$ From a gender perspective, some activists suggest that the movement also created an opportunity to frame feminist concerns within larger solidarities. While these instances of radical politics were short-lived they remain significant as moments in which the dysfunctions of Dayton's afterlives were openly contested. It is unfortunate that, rather than offering support for civic mobilisation, international actors such as the EU continued to privilege stability of the institutions negotiating a new compact for membership which, all rhetoric to the contrary, left many of Dayton's dysfunctions and elites' privileges unaddressed. ${ }^{46}$

Other interviewees describe efforts to find openings for transformation, as small as these might be, within the existing consociational structures. Activists often present this strategy as a pragmatic, yet personally challenging, choice. For instance, a feminist activist whom I interviewed in 2010 illustrates this predicament when reflecting on the challenges and achievements for feminist activism in $\mathrm{BiH}$ :

This is my opinion: I think we have numerous obstacles. There's obstacles in human behaviour: in the perception of women, of gender. We have the challenge of a patriarchal society and then we have also another challenge of the country as it is, its legal division and its legal status. [...] It always amazes me how much we accomplished [compared] to other NGOs movement in gender haven't done in other countries which don't have the obstacles that we have. Because I think that we are all dealing with this patriarchal society, with the position of women, with the political theory but, then again, we have this additional burden. I'm always amazed at how much we actually accomplished and I wonder how much would be able to accomplish if we didn't have this [BiH's complex consociational system]. Those are the things that we cannot fight against, this legal system because then we would be totally accused of not being .. whatever! We are accused now, so I can imagine what it would be then. But I think we are just finding different methods 
of assisting women. I think it is possible but it does take greater effort. It's worth it and I really think is doable. But that's when I really think positive about Bosnia and Herzegovina, there are other days when I think everything is hopeless here... ${ }^{47}$

This narrative still rings true as actors interested in feminist activism and gender equality must constantly negotiate with elements of Dayton's dysfunctional afterlives highlighted so far. The incorporation and application of the WPS agenda into the politics of Post-Dayton Bosnia-Herzegovina is emblematic. The cooperation of several actors working within and beyond the bounds of Dayton's governance are a positive aspect. The creation, monitoring and review of a National Action Plan, in fact, has seen the involvement of women's organisations, the BiH gender Agency and gender centres, national and international security sector institutions. However, developments in some aspects of the agenda, such as the reform of the security sector, have been met with failures that weaken WPS's more ambitious and transformative aims. In this respect, the context of Post-Dayton Bosnia-Herzegovina is consistent with findings emerging from other post-conflict scenarios. ${ }^{48}$ On the other hand, evidence from BiH highlights important context-specific dynamics that in my view are wound up with Dayton's dysfunctional mode of governance. For instance, a point worth considering is the uneven institutional commitment to addresses certain elements of agenda, while resisting or conveniently ignoring others. I suggest that rather than a matter of imperfect implementation, this inconsistency is highly political. It becomes clear that major challenges remain in spheres that undermine the interests of nationalist elites, such as women full and equal participation in public life, access to socio-economic justice, and crucially full-fledged citizenship rights for women survivors. From this perspective WPS implementation relies on a compromised agenda whereby 'progress' can be measured in relation to issues that are not interwoven with the contested legacy of war and, thus, do not challenge the nationalist elites' privileges sustained by the consociational structures.

Despite these failures, the current NAP presents an interesting development which might yield opportunities for a fuller realisation of WPS goals. As mentioned earlier, a new element in the NAP lies in the inclusion of the broader concept of human security as an instrument that enables the localisation of the WPS agenda. ${ }^{49}$ Through this mechanism a number of CSOs in cooperation with the BiH Agency for gender equality, and financial support from UN Women in BH and Fund for the Implementation of the Gender Action Plan in BiH (FIGAP) program, have implemented specific projects aiming to address the needs of women in local $\mathrm{BiH}$ communities. ${ }^{50}$ An interviewee pointed out that the application of localised programmes in the Republika Srpska (RS) might offer opportunities to change the discriminatory legal provisions regulating the status of survivors. ${ }^{51}$ It is premature to assess the outcome of this ongoing process. However, were the RS law regulating access to social rights eventually change, this could represent a significant victory for survivors' rights in Post-Dayton Bosnia-Herzegovina, as well as an important step in integrating WPS into the consociational structures. 
Resulting from the alignment of various interests and actors working on the local legacy of conflict related sexual violence (CRSV) in the Republika Srpska, this development saw the cooperation between UNWomen and the local Gender Centre, as well as involvement of UNFPA in BiH. ${ }^{52}$ Other factors might have also contributed to mount pressure on the issue, such as the presentation of an influential report on the status of survivors in the entity's parliament. Significant is also the international momentum around the Preventing Sexual Violence in Conflict initiative, supported by William Hague and championed by UN Ambassador Angelina Jolie, which momentarily brought popular and political attention to BiH's outstanding war-legacies. ${ }^{53}$. Awaiting future developments on the matter, I suggest that the initiative itself highlights potential to circumnavigate the challenges posed by Dayton's consociational politics through strategic (feminist) partnerships within and beyond the bounds of the local political context. ${ }^{54}$

\section{Conclusion}

This paper highlights key shortcomings in the integration of Women, Peace and Security into the postDayton consociational structures and political agenda. The context of Bosnia-Herzegovina illustrates long-standing gendered ramifications of consociationalism. I have argued that these reach beyond the rhetorical commitment to gender equality and infiltrate the social and discursive fabric of the postwar/post-Dayton order. The sedimentation of nationalist power as a by-product of the settlement has implicitly led to the entrenchment of a patriarchal gender order and pressures for women to conform to traditional gender stereotypes. It has also worked to institutionalise largely unaccountable political elites who continue to prioritise nationalist self-interests and privileges to the detriment of other political issues, such as gender, socio-economic inequality and ordinary citizenship rights. On the other hand, the implementation of a minimalist version of WPS that focuses predominantly on gender balancing of institutions and security sector, fails to address broader gender exclusions emerged at the intersection of post-conflict/post-settlement dynamics. The rhetorical commitment to address the legacy of CRSV offers a sharp reminder that $\mathrm{BiH}$ elites are failing to take Women, Peace and Security seriously. In this context, the Dayton's structural constraints inevitably restrict the political terrain in which activists operate.

Interventions at the grassroots level offer important opportunities for feminist politics "from below". However, their ability to subvert Dayton's multi-layered dysfunctions is constrained even when feminist interventions are inscribed within larger and popular demands for change, such as those emerged in the protest and plenum movements in 2014. Other feminist actors continue to pursue change through the BiH National Action Plan for Women, Peace and Security. Implementation, however, often becomes a mere technical exercise of gender-balancing that, to date, has not substantially altered dominant governance structures and practices of security. While it is difficult to see past rhetorical commitment, new openings for transformative policies might emerge. An interesting example is a 
recent initiative on localised approaches to the legacy of CRSV spurred by the second NAP and by the auspicious convergence of local/international initiatives on the issue. At the intersection of local implementation and favourable feminist constellations, this new inception might be instructive for future developments in integrating WPS into consociational power-sharing institutions. Our task as feminist transnational allies is insisting that, despite a loss of interest in the mainstream international arena, Bosnia and Herzegovina's complex and incomplete peace remains central to the WPS research and activist community.

\section{ACKNOWLEDGMENTS}

I wish to thank Siobhan Byrne, Allison McCulloch, Danielle Roberts and the two anonymous reviewers for insightful comments and productive suggestions. I would also like to thank Ken McDonagh, the Institute for International Conflict Resolution and Reconstruction and the School of Law and Government at Dublin City University for hosting my fellowship and fostering this piece of research. I am indebted to all the research participants who contributed in important ways to developing this piece. Any mistakes I have made are my own.

\section{AUTHOR BIO}

Maria-Adriana Deiana is a Lecturer in International Relations in the School of Law and Government, Dublin City University, Ireland. Drawing on feminist approaches to war and security, her research focuses on conflict transformation, the Women, Peace and Security (WPS) agenda, and EU peacekeeping. 


\begin{abstract}
${ }^{1}$ The literature on the topic is extensive. For a selection of studies see for example : Carol Cohn, Helen Kinsella, and Sheri Gibbings, 'Women, Peace and Security Resolution 1325', International Feminist Journal of Politics 6, no. 1 (2004): 130-140; Torunn L. Tryggestad, 'Trick or Treat? The UN and Implementation of Security Council Resolution 1325 on Women, Peace, and Security', Global Governance: A Review of Multilateralism and International Organizations 15, no. 4 (2009): 539-557; Nicola Pratt and Sophie Richter-Devroe, 'Critically Examining UNSCR 1325 on Women, Peace and Security', International Feminist Journal of Politics 13, no. 4 (1 December 2011): 489-503, doi:10.1080/14616742.2011.611658; Henri Myrttinen, Jana Naujoks, and Judy ElBushra, Re-Thinking Gender in Peacebuilding (International Alert London, 2014), http://www.1325.fi/wordpress/wp-content/uploads/2015/04/HelsinkiPresentationMyrttinen.pdf; Laura McLeod, 'Configurations of Post-Conflict: Impacts of Representations of Conflict and Post-Conflict upon the (Political) Translations of Gender Security within UNSCR 1325', International Feminist Journal of Politics 13, no. 4 (1 December 2011): 594-611, doi:10.1080/14616742.2011.611664; Vanessa Farr, 'UNSCR 1325 and Women's Peace Activism in the Occupied Palestinian Territory', International Feminist Journal of Politics 13, no. 4 (1 December 2011): 539-56, doi:10.1080/14616742.2011.611661; Melanie Hoewer, 'UN Resolution 1325 in Ireland: Limitations and Opportunities of the International Framework on Women, Peace and Security', Irish Political Studies 28, no. 3 (2013): 450-468.
\end{abstract}

2 Ronan Kennedy, Claire Pierson, and Jennifer Thomson, 'Challenging Identity Hierarchies: Gender and Consociational Power-Sharing', The British Journal of Politics and International Relations, 2016, 1369148116647334; Christine Bell, 'Unsettling Bargains?: Power-Sharing and the Inclusion of Women in Peace Negotiations', Political Settlements Research Programme, 2015; Kris Brown and Fionnuala Ní Aoláin, 'Through the Looking Glass: Transitional Justice Futures through the Lens of Nationalism, Feminism and Transformative Change', International Journal of Transitional Justice, 2014, iju027; Bernadette C. Hayes and Ian McAllister, 'Gender and Consociational Power-Sharing in Northern Ireland', International Political Science Review 34, no. 2 (2013): 123-139; Siobhan Byrne and Allison McCulloch, 'Gender, Representation and Power-Sharing in PostConflict Institutions', International Peacekeeping 19, no. 5 (1 November 2012): 565-80, doi:10.1080/13533312.2012.721990; Miki Caul Kittilson and Leslie Schwindt-Bayer, 'Engaging Citizens: The Role of Power-Sharing Institutions', The Journal of Politics 72, no. 04 (2010): 990-1002; Sumie Nakaya, 'Women and Gender Equality in Peace Processes: From Women at the Negotiating Table to Postwar Structural Reforms in Guatemala and Somalia', Global Governance 9, no. 4 (2003): 459-476; Christine Bell, 'Unsettling Bargains?: Power-Sharing and the Inclusion of Women in Peace Negotiations'.

${ }^{3}$ Christine Bell, 'Unsettling Bargains?: Power-Sharing and the Inclusion of Women in Peace Negotiations'.

${ }^{4}$ Byrne and McCulloch, 'Gender, Representation and Power-Sharing in Post-Conflict Institutions'.

${ }^{5}$ Christine Bell, 'Unsettling Bargains?: Power-Sharing and the Inclusion of Women in Peace Negotiations', 6.

${ }^{6}$ The term "gender machineries" usually indicates governmental structures assigned to promote gender equality. In the context of Bosnia these are the Agency for Gender Equality of Bosnia and Herzegovina and the Gender Centres of the BiH Federation and Republika Srpska. I also conducted interviews with representatives of the EU delegation in $\mathrm{BiH}$ and $\mathrm{UN}$ Women, as these agencies contribute to the promotion of gender equality in $\mathrm{BiH}$.

${ }^{7} \mathrm{I}$ am currently working on a monograph emerging from the project titled "Gender and Citizenship: Promises of Peace in Post-Dayton Bosnia-Herzegovina" that analyses interview data and cultural products, installations and media clipping (Deiana forthcoming 2018).

${ }^{8}$ I gathered this information while working in the research project "“'Add Women and Hope? Assessing the Gender Impact of EU CSDP missions". Led by Dr Kenneth McDonagh the project is funded by the Irish Research Council New Horizons Starter Grant Scheme \#loveirishresearch.

9 'Engendering the Peace Process (2000)', Kvinna till Kvinna - Works for Peace and Gender Equality, accessed 15 December 2016, http://kvinnatillkvinna.se/en/publication/2013/04/18/engendering-the-peace-process-2000/.

${ }^{10}$ Christine Chinkin and Kate Paradine, 'Vision and Reality: Democracy and Citizenship of Women in the Dayton Peace Accords', Yale J. Int'l L. 26 (2001): 103.

${ }^{11}$ The Law on gender equality has been amended in 2009 and consolidated in 2010. The second iteration of the Gender Action Plan 2013-2017 is now active.

${ }^{12}$ Ankica Tomić, 'Gender Mainstreaming of the Security Sector in Bosnia and Herzegovina: From the Policy Papers to Reality', Connections: The Quarterly Journal 14, no. 3 (2015): 87-102, doi:http://dx.doi.org/10.11610/Connections.14.3.06.

13 National Action Plan for the Implementation of 1325 available at http://www.peacewomen.org/assets/file/bosniaherzegovina_nationalactionplan_2010.pdf (last accessed 27 Mar. 14) 
${ }^{14}$ See "Action plan for implementation of UNSCR 1325 In Bosnia and Herzegovina For the period 2014-2017" https://www.inclusivesecurity.org/wp-content/uploads/2014/12/BiH-NAP-ENG.pdf (accessed November 16 2016)

${ }^{15}$ Tomić, 'Gender Mainstreaming of the Security Sector in Bosnia and Herzegovina'.

${ }^{16}$ Nicole George and Laura J. Shepherd, 'Women, Peace and Security: Exploring the Implementation and Integration of UNSCR 1325', International Political Science Review 37, no. 3 (1 June 2016): 297-306, doi:10.1177/0192512116636659; Paul Kirby and Laura J. Shepherd, 'The Futures Past of the Women, Peace and Security Agenda', International Affairs 92, no. 2 (2016): 373-392.

${ }^{17}$ Radhika Coomaraswamy, 'Preventing Conflict Transforming Justice Securing Peace. A Global Study on the Implementation of United Nations Security Council Resolution 1325', 2015,

http://wps.unwomen.org/en/highlights/global-study-release; George and Shepherd, 'Women, Peace and Security'.

18 Allison McCulloch, 'Consociational Settlements in Deeply Divided Societies: The Liberal-Corporate Distinction', Democratization 21, no. 3 (2014): 501-518; Byrne and McCulloch, 'Gender, Representation and Power-Sharing in Post-Conflict Institutions'.

${ }^{19}$ The international oversight mechanism, envisioned to mitigate conflict and prevent abuse of power, perversely offered the nationalist elites opportunities to strategically engage in divisive politics in the knowledge that consequences would be averted through external intervention. In later years, as Eric Gordy notes, the well-known argument that Dayton was internationally sponsored and lacked local ownership, precisely because of international oversight, has become an alibi for the elites when calls for political change of any sort are made. see Eric Gordy, 'Dayton's Annex 4 Constitution at 20: Political Stalemate, Public Dissatisfaction and the Rebirth of Self-Organisation', Southeast European and Black Sea Studies 15, no. 4 (2 October 2015): 611-22, doi:10.1080/14683857.2015.1134132; Adis Merdzanovic, “'Imposed Consociationalism”: External Intervention and Power Sharing in Bosnia and Herzegovina', Peacebuilding 5, no. 1 (2 January 2017): 22-35, doi:10.1080/21647259.2016.1264918.

${ }^{20}$ Gordy, 'Dayton's Annex 4 Constitution at 20'; Andrew Gilbert and Jasmin Mujanović, 'Dayton at Twenty: Towards New Politics in Bosnia-Herzegovina', Southeast European and Black Sea Studies, 2016, 1-6.

21 'Open Letter to the International Community', WomenOrganizingForChange, accessed 15 December 2016, http://womenorganizingforchange.org/en/statements/open-letter-to-the-international-community/.

${ }^{22}$ Gordy, 'Dayton's Annex 4 Constitution at 20'.

${ }^{23}$ Timothy A. Donais, 'Dayton +20: Peacebuilding and the Perils of Exclusivity', Peacebuilding 5, no. 1 (2 January 2017): 7-21, doi:10.1080/21647259.2016.1264917.

${ }^{24}$ See "Action plan for implementation of UNSCR 1325 In Bosnia and Herzegovina For the period 2014-2017" https://www.inclusivesecurity.org/wp-content/uploads/2014/12/BiH-NAP-ENG.pdf accessed November 162016 25 'Lokalni Izbori u BiH: Od 417 Kandidata Za Načelnike Općina Samo Je 26 Žena - Klix.Ba', accessed 15 December 2016, https://www.klix.ba/vijesti/bih/lokalni-izbori-u-bih-od-417-kandidata-za-nacelnike-opcinasamo-je-26-zena/160926023.

${ }^{26}$ Elissa Helms, Innocence and Victimhood: Gender, Nation, and Women's Activism in Postwar BosniaHerzegovina (Madison: University of Wisconsin Pres, 2013),

${ }^{27}$ Ibid.

${ }^{28}$ Ibid.

${ }^{29}$ Arijana Aganovic, Edita Miftari, and Marina Veličković, '1995-2015: Women and Political Life in PostDayton Bosnia and Herzegovina’, 2015, http://soc.ba/site/wp-content/uploads/2016/02/1995-2015-eng_zaweb.pdf.

${ }^{30}$ This view was expressed by many of the interviewees who explicitly identify as feminist

${ }^{31}$ The dissatisfaction with the primacy of nationalist politics was shared by the majority of interviewees I have encountered throughout my successive field trips.

${ }^{32}$ SNSD started as a moderate party but it is now classified as a nationalist formation representing Serb interests. His leader Dodik has often threatened the secession of Republika Srpska

see for example Catherine Baker, The Yugoslav Wars of the 1990s, 1st ed. 2015 edition (New York, NY:

Palgrave, 2015).

${ }^{33}$ Personal interview with Dusanka Majikic, incumbent Deputy Speaker for the BiH House of the People, member of SNSD party, Sarajevo 01 April 2010

${ }^{34}$ Personal interview with Lejla Somun-Krupalija, Sarajevo 19 April 2010

35 'Is Bosnia the Worst Place in Europe to Be a Woman? | OpenDemocracy', accessed 6 December 2016, https://www.opendemocracy.net/can-europe-make-it/tea-hadziristic/women-in-bosnia; Adriana Zaharijević, 'Dissidents, Disloyal Citizens and Partisans of Emancipation: Feminist Citizenship in Yugoslavia and PostYugoslav Spaces', Women's Studies International Forum 49 (March 2015): 93-100, doi:10.1016/j.wsif.2014.07.002. 
${ }^{36}$ Personal Interview with Duška Jurišić Sarajevo, 09 September 2010 The media campaign unfolded in the pages of a popular local newspaper incidentally owned by the leader of (Bosniak) nationalist-oriented and populist Party for Better Future (SBB). It revolved around allegations that mobilised the journalist's Serbian ethnicity and her gender to discredit her suitability for holding a post of national(ist) interest such as Federation TV.

37 Oslobodjenje.ba, 'BiH Journalists' Association Sharply Condemns RS President's Verbal Attack on Oslobodjenje Reporter Gordana Katana | DAILY NEWS | Oslobodjenje.Ba', Oslobođenje | Bosanskohercegovačke Nezavisne Novine, accessed 14 March 2016, http:/www.oslobodjenje.ba/daily-news/bihjournalists-association-sharply-condemns-rs-presidents-verbal-attack-on-oslobodjenje-reporter-gordana-katana. ${ }^{38}$ Confidential interview, Sarajevo 26 August 2015

39 'Bosnia Verdict Shows the Tide Is Turning for Leaders Who Use Mass Rape as a Weapon of War', International Business Times UK, 29 March 2016, http://www.ibtimes.co.uk/mass-rape-weapon-war-bosnia-verdict-warningleaders-who-unbolt-heart-darkness-1551989; Julian Borger Diplomatic editor, 'Bosnia Rape Victims May Claim Compensation for First Time', The Guardian, 30 June 2015, sec. World news, https://www.theguardian.com/world/2015/jun/30/bosnia-victims-compensation-landmark-ruling.

${ }^{40}$ Gorana Mlinarević, Nela Porobić Isaković, and Madeleine Rees, 'If Women Are Left out of Peace Talks | Forced Migration Review', 2015, http:/www.fmreview.org/mlinarevic-isakovic-rees.html.

${ }^{41}$ Maria O'Reilly, 'Peace and Justice through a Feminist Lens: Gender Justice and the Women's Court for the Former Yugoslavia', Journal of Intervention and Statebuilding 10, no. 3 (2 July 2016): 425, doi:10.1080/17502977.2016.1199482.

${ }^{42}$ Helms, Innocence and Victimhood; Brown and Aoláin, 'Through the Looking Glass'.

${ }^{43}$ Daniela Lai, 'Transitional Justice and Its Discontents: Socioeconomic Justice in Bosnia and Herzegovina and the Limits of International Intervention', Journal of Intervention and Statebuilding 10, no. 3 (2 July 2016): 36181, doi:10.1080/17502977.2016.1199478; Cera Murtagh, 'Civic Mobilization in Divided Societies and the Perils of Political Engagement: Bosnia and Herzegovina's Protest and Plenum Movement', Nationalism and Ethnic Politics 22, no. 2 (2016): 149-171.

${ }^{44}$ Confidential personal interview Sarajevo 24 August 2015

45 The Plenums are citizens' assemblies organised by activists during the protests to discuss political issues and make demands to the institutions For additional resources on the Protests and Plenum movement as examples of radical politics see Damir Arsenijević, Unbribable Bosnia and Herzegovina: The Fight for the Commons (Nomos Verlagsgesellschaft, 2015).

${ }^{46}$ Danijela Majstorović, Zoran Vučkovac, and Anđela Pepić, 'From Dayton to Brussels via Tuzla: Post-2014

Economic Restructuring as Europeanization Discourse/Practice in Bosnia and Herzegovina', Southeast

European and Black Sea Studies 15, no. 4 (2 October 2015): 661-82, doi:10.1080/14683857.2015.1126093.

${ }^{47}$ Personal Interview with Udružene Žene activist, Banja Luka, BIH, 25 August 2010

${ }^{48}$ Radhika Coomaraswamy, 'Preventing Conflict Transforming Justice Securing Peace. A Global Study on the Implementation of United Nations Security Council Resolution 1325'; Paul Kirby and Laura J. Shepherd, 'Reintroducing Women, Peace and Security', International Affairs 92, no. 2 (2016): 249-254.

${ }^{49}$ Kirby and Shepherd, 'The Futures Past of the Women, Peace and Security Agenda'.

${ }^{50}$ BiH Action Plan, 2014 p. 21

${ }^{51}$ Personal Interview with UNWomen representative 28 September 2016

52 'Sound of Silence: Dealing with the Legacy of Sexual Violence as a Weapon of War|UNFPA - United Nations Population Fund', accessed 19 December 2016, http://www.unfpa.org/news/sound-silence-dealing-legacysexual-violence-weapon-war; 'UNFPA Bosnia and Herzegovina | Combating Sexual Violence in Conflict', accessed 19 December 2016, http://ba.unfpa.org/publications/combating-sexual-violence-conflict.

53 Personal Interview with UNWomen representative 28 September 2016, see also https://www.gov.uk/government/policies/sexual-violence-in-conflict

${ }^{54}$ On the notion of feminist constellations and strategic feminist partnerships see Roberta Guerrina and Katharine AM Wright, 'Gendering Normative Power Europe: Lessons of the Women, Peace and Security Agenda', International Affairs 92, no. 2 (2016): 293-312; Alison Woodward, 'Building Velvet Triangles: Gender and Informal Governance', Informal Governance in the European Union. Cheltenham: Edward Elgar, 2004, 76-93. 